Peer-Reviewed Article

\title{
What Role Do You Play? Faculty Perceptions of Librarian-led Information Literacy Instruction
}

Moddie V. Breland, Mercy College

\begin{abstract}
This study explored faculty perceptions of librarian-led information literacy instruction using Interpretative Phenomenological Analysis. Semi-structured interviews were conducted with six faculty who taught undergraduate general education courses. The overarching theme of this study was that faculty believe their role in teaching information literacy differs from librarians. The participants thought faculty were responsible for teaching information literacy through direct instruction and assigning course work, while the librarians were responsible for teaching the research process. This study suggests that there are opportunities for librarians to further assess how faculty incorporate information literacy concepts into their classroom.

\section{KEYWORDS}

Information literacy instruction, faculty perceptions, academic libraries
\end{abstract}

\section{SUGGESTED CITATION}

Breland, M. (2022). What role do you play? Faculty Perceptions of Librarian-led Information Literacy Instruction. Journal of New Librarianship, 7(1), 106-125.

https://doi.org/10.33011/newlibs/11/12

This is an Open Access article distributed under the terms of the Creative Commons Attribution 4.0 International License (http://creativecommons.org/licenses/by/4.0), which permits unrestricted use, distribution, and reproduction in any medium, provided the original work is properly cited. 


\section{Introduction}

According to the 2010 Project Information Literacy study, eighty percent of 8,353 surveyed across 25 U.S. campuses reported having trouble with starting their research assignments (Head, 2013). Project Information Literacy also reported that half of the students surveyed experienced difficulty finding, assessing, and using information to solve problems (Head, 2013). Despite the challenges higher education has with meeting the needs of students with varying levels of information literacy skills (Buzzetto-Hollywood et al., 2018), the number of Librarian-led Information Literacy (LIL) instruction sessions have declined (Hayes et al., 2018; Kline et al., 2017; Leeder \& Loon, 2014; Saunders, 2013; White-Farnham \& Gardner, 2014). Declines in LIL are troubling because librarians are starting to use strengths-based or holistic approaches to teach information literacy skills (Heinbach et al., 2019). Instead of having a deficit mindset that ignores the students' strengths, librarians use pedagogical methods that build on what students already know (Heinbach et al., 2019).

Faculty recognize the importance of information literacy and acknowledge that their students are deficient in this area, but they often resist opportunities to collaborate with librarians to improve this competency (McGuinness, 2006; Saunders, 2013). To better serve the needs of today's college students, "a more expansive and nuanced understanding of how faculty perceive information literacy" is required to develop information literacy programs and curricula (Cope \& Sanabria, 2014, p. 476). Since the college landscape has shifted so drastically over the years, it is critical to investigate what role faculty believe librarians play in teaching information literacy.

The purpose of this Interpretative Phenomenological Analysis (IPA) study was to gain insight into the lived experiences of undergraduate faculty who participate in LIL instruction and what role they believed librarians played in teaching information literacy.

\section{Literature Review}

\section{Information Literacy Instruction}

According to the Association of College and Research Libraries (2000) information literacy competency standards for higher education, an information literate student can recognize a need for information and can subsequently locate, evaluate, and effectively use the needed information. In addition, information literacy "empowers learners with the skills, attitudes, behaviours, and understandings that they will need to make appropriate and informed choices within both current and future endeavours" (Hicks \& Lloyd, 2021, p. 564). Therefore, information literacy instruction is critical to students becoming independent thinkers and active learners (Rosman et al., 2018).

According to Rosman et al. (2018), information literacy instruction has several beneficial outcomes. Information literacy instruction teaches students to locate and evaluate information so they can search databases, formulate appropriate search terms, and assess the quality of the 
information retrieved (Rosman et al., 2018). Information literacy instruction also enables students to develop comprehensive knowledge on a topic, so they gain expertise in their field of inquiry (Rosman et al., 2018). Furthermore, information literacy Instruction is critical because it reduces anxiety, boosts confidence, and directs the student to the appropriate path for finding information (Bapte, 2019).

\section{Impact of Information Literacy Instruction on Student Success}

Information literacy instruction has shown to have a positive correlation with student success indicators (Black \& Murphy, 2017; Bowles-Terry, 2012; Cook, 2014; Soria et al., 2017; Squibb \& Mikkelsen, 2016; Wang, 2006; Wong \& Cmor, 2011). Wang (2006) noted that students who completed library credit-bearing courses performed better in their classes and received higher grades. Wong \& Cmor (2011) observed that the more students were exposed to information literacy instruction, the higher their overall grade point average (GPA). BowlesTerry (2012) found a significant difference in GPA between graduating seniors who were offered information literacy instruction in upper-level courses compared to those who were not.

In addition to having an impact on GPA, information literacy instruction has been shown to influence retention, persistence, and graduation rates (Catalano \& Phillips, 2016; Cook, 2014; Eng \& Stadler, 2015; Selegean et al., 1983; Soria et al., 2017). Soria et al. (2017) concluded that students who participated in information literacy instruction courses had a significantly higher probability of remaining enrolled in college. Cook (2014) reported that students who completed library credit-bearing courses graduated at a considerably higher rate than those who did not enroll in such classes. Cook (2014) also found that students whose overall GPA decreased between the transition from high school to college were more likely to graduate if they completed a library credit-bearing course compared to those who did not enroll in the course. Lastly, Selegean et al. (1983) found that students who finished library credit-bearing courses had a higher persistence rate than those who did not take the classes but had similar GPAs and SAT scores.

\section{Faculty Perception of Information Literacy Instruction}

Although faculty across disciplines believed the competencies associated with information literacy were essential to student success (Saunders, 2012), many resisted having LIL instruction in their courses (Johnson-Grau et al., 2016; Meulemans \& Carr, 2013; Singh, 2005). According to Zanin-Yost and Dillen (2019), one of the reasons faculty neglected to collaborate with librarians was that they were unaware of the library's instructional services. Faculty may also be disinclined to have LIL instruction sessions because they do not want to yield class time (Zanin-Yost \& Dillen, 2019). Leckie and Fullerton (1999) noted that faculty failed to collaborate with librarians because they were unfamiliar with the complex roles libraries and librarians play in higher education. Saunders (2012) added that faculty were hesitant to integrate LIL instruction in their courses because they were confused by the definition of information literacy. This lack of clarity on the meaning of information literacy has 
caused faculty to focus on course content and assume information literacy skills would be learned indirectly through coursework (Saunders, 2012).

Some other notable reasons faculty are not inclined to have LIL instruction in their courses are due to the misconceptions regarding information literacy, such as what it entails, how students develop information literacy skills, and who should teach it (Raven, 2012; Weiner, 2014; Vander Meer et al., 2012). The problem with embedding LIL instruction into a course is compounded by the fact that faculty perceptions or misconceptions of information literacy vary depending on the discipline (Leckie \& Fullerton, 1999; Pinto, 2016). Weiner (2014) noted that since information literacy was relevant to all disciplines, it was not apparent to faculty who were responsible for integrating it into the curricula.

Grafstein (2002) argued that faculty were responsible for teaching information literacy skills germane to their discipline's research methods and procedures. Similarly, Weiner (2014) concluded that many faculty believed they were responsible for teaching information literacy skills, such as finding articles and avoiding plagiarism. Vander Meer et al. (2012) asserted that faculty felt students should already have appropriate information literacy competencies when they enroll in a particular course. Vander Meer et al. (2012) added that any gaps in those skills would be learned through instruction and coursework (Vander Meer et al., 2012). Dawes (2019) found that faculty viewed librarians as responsible for providing services and managing collections more than teaching classes.

Faculty were also reticent to include LIL instruction in their courses because they believed it was learned when students were self-motivated and proactive (McGuinness, 2006). Faculty also surmised that information literacy skills were not retained by attending several instructional sessions but were developed over time (Dubicki, 2013; McGuinness, 2006; Sandercook, 2016). Faculty thought students learned information literacy skills by engaging with course material and through the process of trial and error (McGuinness, 2006). Dubicki (2013) noted that faculty believed their course assignments had more impact on information literacy skills than LIL instruction. Dubicki (2013) also uncovered that faculty felt it was their responsibility to teach information literacy and not just librarians. Cope and Sanabria (2014) found that faculty thought information literacy skills were not acquired linearly. The faculty in their study "viewed the development of information literacy skills as a continuous and unfolding process that only becomes crystallized [by completing] specific educational products such as research papers or presentations" (Cope \& Sanabria, 2014, p. 492).

\section{Faculty Experiences Collaborating with Librarians}

In many institutions of higher learning, there is a need to fortify the relationship between librarians and faculty (Cowan \& Eva, 2016; Kotter, 1999) because there is a barrier between faculty and academic librarians concerning collaboration. Badke (2005) and Ducas and Michaud-Oystryk (2003) pointed out that librarians and faculty have different instructional 
priorities. Badke (2005) argued, in his research on the relationships between faculty and librarians, that librarians' instructional priorities were on general information literacy skills that addressed the research process and went beyond the boundaries of a particular discipline. Faculty prioritize teaching the content in a discipline instead of the broader skills acquired outside of the discipline (Badke, 2005). While exploring how faculty collaborate with librarians, Ducas and Michaud-Oystryk (2003) observed that faculty believed they were responsible for teaching core content while librarians were responsible for teaching supplemental and peripheral material.

McGuinness (2006) found that the tension between librarians and faculty was partly due to how territorial and possessive faculty were about their course curriculum. Snavely \& Cooper (1997) asserted that the rift between faculty and librarians stems from two factors. First, faculty do not believe librarians are experts in their discipline. Secondly, faculty think librarians try to take too much control over the direction of their class. Feldman and Sciammarella (2000) stated that most faculty believed they were just as capable of teaching students information literacy skills, as it relates to their course, as librarians.

When faculty are willing to collaborate with librarians, it has shown to have tremendous benefits (Delaney \& Bates, 2015; Kotter, 1999; Mounce, 2010; Sanborn, 2005; Zanin-Yost \& Dillen, 2019). A benefit to the collaborative efforts of librarians and faculty is increased usage of the library by faculty and the students they teach (Sanborn, 2005). Sanborn (2005) asserted that an increase in library usage generally justifies requests for additional funding and programming. Another advantage to a librarian and faculty collaboration is that instructors who have a pleasurable experience with librarians will be more likely to use the library's services again (Maughan, 2001).

Several research studies have indicated that faculty generally have positive experiences collaborating with librarians (Bury, 2011; Hall, 2008; Mounce, 2010; Yousef, 2010). Bury (2011) uncovered that faculty believed LIL sessions have a substantial impact on student learning. Bury (2011) noted that the faculty surveyed thought the information literacy sessions helped the students improve on their course assignments and research skills. However, Leckie and Fullerton (1999) cautioned that even though faculty may appreciate a LIL session, they might not be able to assess what the students learned.

\section{Method}

\section{Interpretative Phenomenological Analysis}

The qualitative research methodology used for this study was Interpretative Phenomenological Analysis (IPA), which facilitates the exploration of how people make sense of their life experiences (Alase, 2017). IPA research methodology was used because it uncovers the experiential accounts from participants by asking them to describe events, relationships, or emotions they may feel (Shaw, 2010). From an individualized or idiographic perspective, IPA 
research seeks to understand a person's lived experiences and the sense the person makes of what is happening to them (Smith et al., 2009, p. 3).

IPA is influenced by two theoretical traditions: phenomenology and hermeneutics (Shaw, 2010). A German philosopher named Edmund Husserl developed the philosophy of phenomenology. Husserl formalized the philosophy of phenomenology to establish it as a rigorous and unbiased approach to understanding human consciousness and experience (Shosha, 2012). Phenomenology aims to gain a deeper understanding of a person's lived experiences and the phenomenon experienced by the person (Shosha, 2012). Phenomenologists seek answers to questions such as "What is the experience like? What is the essence of the phenomenon experienced? What is the meaning of the phenomenon to the people who are experiencing it?" Hermeneutics is the process or method of bringing out the hidden meaning from the human experience. IPA researchers employ a double hermeneutic whereby they try to "make sense of the participant trying to make sense of what is happening to them" (Smith et al., 2009, p. 3).

The premise of interpretative phenomenology is that an individual's reality is inextricably influenced and cannot be separated from the world they live in (Lopez \& Willis, 2004). The interpretative phenomenological approach relies on "understanding and co-creation by the researcher and the participants" to ensure the investigator's interpretations are meaningful and valid (Wojnar \& Swanson, 2007, p. 176). Since this study sought to explore faculty experiences and the role they believed librarians played in teaching information literacy, IPA research methodology was used to frame the research question and collect data. IPA research focuses on subjects' views, perceptions, and lived experiences (Smith et al., 2009). In terms of data collection, the IPA research methodology allows a researcher to solicit from their subjects "rich, detailed, first-person accounts of their experiences" (Smith et al., 2009, p. 56).

\section{Study Design}

IPA was used to uncover experiential accounts from participants by asking them to describe events, relationships, and emotions they may have felt. The study consisted of six participants who experienced a LIL session from the same private, nonprofit institution. Since IPA research is highly detailed, in-depth, and committed to understanding how individuals understand phenomena in a particular context, a small, purposive, and carefully situated sample was used for analysis (Smith et al., 2009). Consistent with the recruitment strategy of IPA researchers, six full-time undergraduate faculty who engaged in LIL sessions were purposively sampled. The rationale for recruiting all undergraduate faculty from the same school was to preserve the homogeneity of the testing population. Instead of using a sample representative of the population with varying perspectives, IPA research explores the perspective of a group with similar characteristics or within a similar context (VanScoy \& Evenstad, 2015). IPA researchers use homogeneous populations that are meaningful to the research question of their study (Smith et al., 2009). 
After securing Institutional Review Board (IRB) approval, qualified participants identified based on library instruction request records were emailed about the study. Each participant was scheduled for two in-person interviews in a location of their choosing and assigned a pseudonym. Each interview lasted between 30 to 90 minutes and, all six participants gave consent to have their interviews audio-recorded and transcribed. The researcher conducted the first interview for 60 to 90 minutes using a semi-structured interview schedule. The first interview aimed to ascertain how the participants made meaning of LIL instruction. The researcher administered the second interview for 30 to 45 minutes and asked follow up questions based on the first interview. The participants were also asked to complete a member checking form during the second interview. Member checking is a process that allows a researcher to validate their data analysis by returning to the study subjects for a second interview (Birt et al., 2016). The benefits of member checking are that it mitigates a researcher's bias and enhances the rigor of qualitative research by ensuring the analyzed data is accurate and credible (Birt et al., 2016).

The data analysis was executed in several steps and was consistent with those outlined by VanScoy and Evenstad (2015), Smith et al. (2009), and Shaw (2010). The first step involved reviewing the participant's transcript in tandem with listening to the corresponding audio recording. This process ensured that the participant was the focus and not part of the researcher's inclination for making reductions and summaries (Smith et al., 2009).

After transcribing the interviews, the initial noting process was conducted, which involved examining semantic content and language use (Smith et al., 2009). Initial noting helps the researcher identify "specific ways by which the participant talks about, understands and thinks about an issue" (Smith et al., 2009, p. 83). The central goal of this step was to describe key objects of concern for the participant, such as relationships, values, and principles (Smith et al., 2009). In addition to initial noting, conceptual noting was used to focus on the subject's overarching understanding of what role they believed librarians played in teaching information literacy. Conceptual noting is an exploratory commenting strategy that "draws on the researcher's experiential and/or professional knowledge" and connects these preunderstandings with the "newly emerging understandings of the participant's world" (Smith et al., 2009, p. 89).

In order to identify the emergent themes, the initial notes and the exploratory comments were re-examined and organized thematically (VanScoy \& Evenstad, 2015). Once the emergent themes were identified, the next step was to produce a statement that articulated what was important about each theme (Smith et al., 2009). The emergent themes did not only reflect "the participant's original words and thoughts but also the analyst's interpretation" (Smith et al., 2009, p. 92). The connections and patterns between emergent themes were identified using an IPA manual analytic process called abstraction (Smith et al., 2009). The process of abstraction occurs when a superordinate theme is created by merging several similar emergent themes 
(Smith et al., 2009). After the participants' responses were reviewed individually, the researcher then looked for patterns across the cases to create a superordinate theme, which are clusters of related emergent themes.

\section{Findings and Discussion}

The superordinate theme that surfaced from the participant responses was the belief that faculty and librarians have distinctive roles in teaching students information literacy skills. Four emergent themes were clustered to create the superordinate theme (Table 1). The four emergent themes were: (a) faculties' role in teaching information literacy, (b) faculties' role in incorporating information literacy in assignments, (c) Librarians' role in teaching information literacy inside and outside the classroom, and (d) librarians' role in supplementing instruction.

\section{Teaching Information Literacy}

The general sentiment among the participants was that they were responsible for teaching information literacy to students. Rachel emphasized how seriously she took her responsibility for teaching information literacy by stating,

This also sounds strange, but if they don't want to learn from themselves, they will learn from me because they know that I'm so incredibly invested in that they do well. And so, once that foundation is laid down, you can go anywhere from there.

Although librarians were typically assigned to teach information literacy in general education courses, Mary felt it was still her duty to ensure her students achieved those learning outcomes. Mary explained that despite the usefulness and expertise of librarians, she had a responsibility to teach students information literacy skills such as finding information in databases. She said,

I wouldn't say that it's... not part of my responsibility to show them that... I have done it in the past, but it's nice to be able to have someone else doing that, and someone who specializes in it. I don't think there's anything that I don't feel like, as an instructor, is my responsibility with information literacy.

Similar to Rachel and Mary, Marcus and Lucas believed instructors have a critical role in teaching information literacy to students. They asserted that instructors should teach information literacy by modeling and practicing those skills in the presence of students. Marcus felt all faculty should consider at least modeling best practices for information literacy "no matter what course they were teaching." He explained faculty should be "engaging" in or modeling information literacy skills because students need these competencies reinforced to be useful. Marcus argued information literacy “...can't be something that's just taught in seminars. It can't be something that's just taught at the libraries. It has to be integrated across the curriculum for it to be effective." 
In agreement with Marcus, Lucas also felt faculty must teach information literacy through modeling and engaging in best practices. Lucas stated that instructors "have to provide direct instruction, which has to include some attempt to persuade students of the value of this skill to themselves in their personal lives, their professional lives, and their civic lives." He further explained,

Faculty should also model information literacy by practicing it in their own work and in their own relationships with students. Faculty need to show that they are evidenceguided, and they are open-minded, and they need to incentivize and reward criticism of themselves in their information practices.

As the participants discussed their experiences with LIL instruction, it became apparent that they believed faculty and librarians' areas of instructional focus were distinct. Contrary to Weiner (2014), who noted that faculty were not sure who was responsible for teaching information literacy, the participants in this study believed it was a skill faculty needed to teach. In addition, the participants thought it was not the sole responsibility of librarians to teach information literacy. They felt a faculty member's role in teaching information literacy competencies was just as significant.

\section{Incorporating Information Literacy in Assignments}

The participants thought their responsibility for teaching students information literacy was to incorporate assignments in the course focusing on those competencies. Mary stated, "My role in helping them become information literate is to give multiple assignments throughout the semester that, in some way, push them to access information, interpret information, [and] evaluate information..." She believes students should be taught information literacy skills through a scaffolding approach. Mary stated that information literacy "needs to sort of be scaffolded into students' experiences, like as they're progressing in college, and maybe going more in-depth as they specialize in a major.” Mary stressed the importance of integrating information literacy in assignments and using a scaffold approach because she believed "it's just something that they [students] need to practice." She admonished that if students do not build on their information literacy competencies "like anything else, they lose those skills over time." Juan reiterated Mary's point by underscoring the importance of incorporating information literacy in an assignment. Juan stated,

if you develop the right questions and the right assignments for them, then that should lead them to the library, where they then [can] ask the right questions... So, we [faculty] have a huge responsibility to develop our assignments in such a way that it leads to curiosity, that it leads them to the library to try to find answers.

In agreement with the other participants, Matt felt information literacy should be integrated into course assignments. Matt explained that he embeds information literacy assignments, such as identifying secondary sources, into his courses because students were 
unaware of some of the fundamental knowledge "necessary to understand their field." Matt believed students lacked the necessary information literacy skills to conduct research in the discipline they intended to pursue in college. Marcus surmised that all courses should have an information literacy component embedded in the course because if faculty were "going to have students even engage in basic research, that's a kind of information literacy."

The findings suggest the participants did not expect students to already have sufficient information literacy skills before taking college level courses. The participants cited scaffolding assignments, modeling correct information seeking behaviors, and engaging in best practices of finding information in the presence of students as ways information literacy competencies are learned and reinforced. This finding was similar to Perry (2017), who found that faculty reinforced information literacy skills through various techniques such as direct instruction, scaffolded assignments, and collaborating with librarians. As uncovered by Weiner (2014), the participants in this study also considered it critical for faculty to enhance students' information literacy skills through course assignments. The participants felt it was their role to integrate information literacy skills into the curricula by designing assignments that helped students understand a particular field of study. As one participant stated, the assignment should lead them "to the library to try to find answers." The participants did not mention that students learned information literacy by self-motivation, as McGuiness (2006) suggested. Instead, all of the participants were convinced these skills were learned through practice.

\section{Librarians Teaching Information Literacy Inside and Outside the Classroom}

A subtheme that emerged from the data was that librarians were responsible for teaching information literacy inside and outside the classroom. The participants held this viewpoint because they recognized the expertise librarians have with technology and as researchers. Juan said librarians have a role in the classroom because faculty "don't have the same ability that librarians have to stay on the cutting edge for how information is available, especially in this day and age." When commenting on how he feels about LIL sessions, Juan stated that he valued the expertise librarians bring to the classroom. He commented

I know my subject; I know my discipline... [and] I know how to go about the research for my particular field. I don't necessarily know how to do it for all of the disciplines, and I wouldn't want to even attempt that. So, I rely on them [librarians] to know the latest and the newest and what is out there...

Echoing a similar sentiment as Juan, Matt said librarians should be in the classroom because "librarians have the skill of knowing how to access information. They also are now very tech-savvy, so they're very adept at manipulating websites in order to gain what they're after." Sharing the same position as both Juan and Matt, Rachel said,

I'm so happy whenever they [librarians] come... I think librarians, they know a little bit of everything across the disciplines... And librarians are the smartest, coolest people I 
know because they just know so much, and they're constantly surrounded by information and research and they're computer literate and they're research literate... It's a teacher's dream come true to have that stuff taught.

The participants also believed librarians have the task of teaching information literacy skills outside of the classroom. Matt and Juan thought librarians have a role in empowering students to help themselves. Matt stated, "I think the librarian can assist a student in becoming more independent as opposed to so many students who are either dependent or indifferent." Juan added that librarians have the obligation of helping students become lifelong learners. Juan explained, "librarians are the home to all of the information and research, and so it's really your responsibility to make them lifelong learners." Lucas asserted a librarian's duty for teaching and promoting information literacy expands beyond the college community. He said, "I think that librarians have a broader civic responsibility to the intellectual community of which they're a part to defend freedom of inquiry, freedom of thought, and freedom of information. Which could extend beyond the campus boundaries even.”

Mary and Marcus emphasized how crucial it was for librarians to be a resource for research help outside of the classroom. Mary stated,

It's really great to be able to know who the librarians are and kind of have like, as an instructor, like know that that's a resource that I have and that my students have. So, if they are having trouble finding a source or if they... like if they've emailed me and said, 'I can't find any journal articles or whatever,' and I'll talk them through it, but I could also tell them, 'You could go to the library and speak with a librarian and they could walk you through that as well.'

Marcus thought librarians played "a pretty big role" teaching information literacy outside of the classroom by "helping students engage in research" and "being a resource for students." He added, "outside the classroom librarians are going to be resources for students who are in need and because of the nature of that relationship you're answering the questions that they have." Rachel stated that librarians "help in the learning process" by being available outside of the classroom. She noted that students could "just call them [librarian]" or "chat with them [librarian]" if they needed help with citations or research.

The participants thought librarians were responsible for teaching information literacy inside and outside the classroom. Dawes (2019) noted that faculty viewed librarians as tasked with providing services and managing collections more so than teaching classes. However, Dawes (2019) conclusions contradict this study's findings. The participants considered the librarians partners in pedagogy and on "equal footing." They felt the librarians' instructional role was to teach students information literacy skills that empowered them, helped them become independent, and enabled them to become lifelong learners. Interestingly, several participants engaged in LIL instruction because they valued the librarians' research and 
technological expertise. Given the prevalence of computers and the internet, this finding was unexpected.

\section{Supplemental Instruction}

The participants interviewed felt the librarians' responsibility in teaching information literacy was to provide supplemental instruction. Juan and Rachel explained they had used a librarian's expertise to teach information literacy competencies they felt uncomfortable with teaching. Juan stated,

I know that one of the things that I keep hearing from other disciplines... Well, I am not a writing professor, I am a professor of philosophy. Well, how is our students going to learn how to write unless you, as a professor, are going to find some way to get them instruction in writing from your course? It's the same thing for me for information literacy. It's one of our competencies. I know my course needs to focus on that. Why not invite the expert in to be able to do that instruction? Then I know the instruction's being done correctly and done [to the] fullest, rather than if I had attempted to do it.

Regarding librarians supplementing faculty instruction, Rachel also utilized librarians to support her in areas of information literacy she felt uncomfortable teaching. Rachel declared librarians "supplement my teaching and where my weaknesses are, they strengthen it. They come in with strength where I can't do it. I can do it, but don't want to do it, and I don't do it very well."

Although all of the participants understood a librarian's role in teaching information literacy was to supplement instruction, some of the participants asserted it was not the librarian's role to teach course content. Marcus opined,

I don't think librarians have to, I mean, in terms of instruction they can certainly offer supplemental instruction. I don't think they're not teaching faculty... Generally speaking, I don't see the librarians as being primarily responsible for classroom content or classroom instruction, things like that. It's like I said, it's supplemental rather than primary. I mean that would be I suppose one place where I might draw a boundary where it's reasonable to expect... That's where I would say I would draw the line.

Although Mary knows some librarians are subject specialists, she reasoned it was not necessary for librarians to teach course content because that was the role of the instructor. Mary responded,

I think that it's the responsibility of the instructor to give a really thorough account of what is the assignment that I'm looking for, why am I having you do this, giving context and background and talking about how literature and studies and knowledge are all created and used in the field because the librarians shouldn't have to do that for you know all the different majors we have here. 
Matt commented a librarian does not have an obligation to teach course content even if they have credentials in a related discipline. He delineated a line between the responsibilities of faculty and librarians as it pertained to teaching course content in credit bearing courses. Matt articulated, "I don't think the librarian has a role in teaching the content of the course." He continued by stating, "That's not their specialty, although they have those specialties, but the students need to know the demarcation line where you go for the information on content and where you go for information [on] how to research information on that content." Although Matt believed librarians should not teach course content, he did not perceive their supplemental role negatively. Matt remarked he recognized librarians as "partners" in pedagogy and not as a "subordinate." He understood the work librarians do as "one group of faculty helping another group of faculty on equal footing". The faculty thought librarians should supplement instruction by teaching the research process as opposed to teaching course content.

The participants thought librarians were responsible for supplementing instruction by teaching the research process instead of course content. Badke's (2005) assertion that librarians and faculty have different instructional priorities substantiates this finding. The participants in this study acknowledged the differences in instructional priorities by stating how librarians teach information literacy skills that go beyond the boundaries of a particular discipline. Their focus on teaching information literacy competencies was confined to their discipline, as Grafstein (2002) concluded. Although the participants knew librarians have a subject specialty, they thought librarians should supplement instruction by teaching the research process rather than course content. Ducas and Michaud-Oystryk's (2003) research supports this finding; they concluded that faculty believed they were responsible for teaching core content while librarians were responsible for teaching supplemental and peripheral material.

\section{Conclusion}

This study sought to expand the research on how faculty make meaning of librarian roles in teaching information literacy. By understanding faculty perceptions, librarians can improve their instructional techniques and outreach efforts. Furthermore, librarians can gain insight on how to address faculties hesitance to collaborate with librarians for pedagogical purposes (Kim \& Shumaker, 2015). Although faculty recognize the importance of LIL, the obstacle of embedding it into their curriculum remains. Compared to existing literature, this study similarly concludes that faculty believe they are partners with librarians in teaching information literacy, even though they have different areas of instructional focus. Librarians could improve their outreach efforts by acknowledging the conflicting views about their roles in teaching information literacy. Faculty have varying confidence levels in teaching information literacy, so there may be an opportunity for librarians to support students by working with the faculty outside of the classroom. Librarians could create continuing education opportunities for faculty by holding workshops that focus on creating assignments that build information literacy skills without a LIL session (Moran, 2019). Furthermore, librarians should consider collaborating 
with faculty to ensure LIL instruction addresses the exact need of the faculty they are partnering with. Either approach would help librarians provide LIL instruction that is both needed and wanted.

The small sample size of faculty limited this study. Consequently, this prevents these findings from being generalizable to larger populations or other types of institutions. Another limitation is that the results may have been impacted by participant self-selection. The faculties' willingness to participate could have influenced some of the responses given in the interview.

Further qualitative research is needed to understand what role faculty believe librarians serve in promoting and teaching information literacy. Future studies could also explore how librarians could provide faculty with professional development opportunities on embedding information literacy competencies in their curriculum. There is also a need to reexamine faculty culture and how it influences collaboration between faculty and librarians. Hardesty (1995) noted that faculty culture inherently resists change. Understanding faculty culture and its impact on LIL instruction would help librarians' outreach efforts. 


\section{References}

Alase, A. (2017). The interpretative phenomenological analysis (IPA): A guide to a good qualitative research approach. International Journal of Education and Literacy Studies, 5(2), 9-19. https://doi.org/10.7575/aiac.ijels.v.5n.2p.9

Association of College \& Research Libraries. (2000). ACRL standards: Information literacy competency standards for higher education. College \& Research Libraries News, 61(3), 207-215. https://doi.org/10.5860/crln.61.3.207

Badke, W. B. (2005). Can't get no respect: Helping faculty to understand the educational power of information literacy. The Reference Librarian, 43(89-90), 63-80. https://doi.org/10.1300/J120v43n89 05

Bapte, V. D. (2019). Information literacy instruction: Determining the place of library professionals. DESIDOC Journal of Library \& Information Technology, 39(1), 39-46. https://doi.org/10.14429.djlit.39.1.13676

Birt, L., Scott, S., Cavers, D., Campbell, C., \& Walter, F. (2016). Member checking: A tool to enhance trustworthiness or merely a nod to validation? Qualitative Health Research, 26(13), 1802-1811. https://doi.org/10.1177\%2F1049732316654870

Black, E. L., \& Murphy, S. A. (2017). The out loud assignment: Articulating library contributions to first-year student success. The Journal of Academic Librarianship, 43(5), 409-416. https://doi.org/10.1016/j.acalib.2017.06.008

Bowles-Terry, M. (2012). Library instruction and academic success: A mixed-methods assessment of a library instruction program. Evidence Based Library and Information Practice, 7(1), 82-95. https://doi.org/10.18438/B8PS4D

Bury, S. (2011). Faculty attitudes, perceptions, and experiences of information literacy: A study across multiple disciplines at York University, Canada. Journal of Information Literacy, 5(1), 45-64. https://doi.org/10.11645/5.1.1513

Buzzetto-Hollywood, N. A., Elobeid, M., \& Elobaid, M. E. (2018). Addressing information literacy and the digital divide in higher education. Interdisciplinary Journal of e-Skills and Lifelong Learning, 14, 77-93. https://doi.org/10.28945/4029

Catalano, A. J., \& Phillips, S. R. (2016). Information literacy and retention: A case study of the value of the library. Evidence Based Library and Information Practice, 11(4), 2-13. https://doi.org/10.18438/B82K7W

Cook, J. M. (2014). A library credit course and student success rates: A longitudinal study. College \& Research Libraries, 75(3), 272-283. https://doi.org/10.5860/crl12-424 
Cope, J., \& Sanabria, J. E. (2014). Do we speak the same language? A study of faculty perceptions of information literacy. Portal: Libraries and the Academy, 14(4), 475-501. https://doi.org/10.1353/pla.2014.0032

Cowan, S., \& Eva, N. (2016). Changing our aim: Infiltrating faculty with information literacy. Communications in Information Literacy, 10(2), 163-177. https://doi.org/10.15760/comminfolit.2016.10.2.31

Dawes, L. (2019). Faculty perceptions of teaching information literacy to first-year students: A phenomenographic study. Journal of Librarianship and Information Science, 51(2), 545560. https://doi.org/10.1177/0961000617726129

Delaney, G., \& Bates, J. (2015). Envisioning the academic library: A reflection on roles, relevancy, and relationships. New Review of Academic Librarianship, 21(1), 30-51. https://doi.org/10.1080/13614533.2014.911194

Dubicki, E. (2013). Faculty perceptions of students' information literacy skills competencies. Journal of Information Literacy, 7(2), 97-125. https://doi.org/10.11645/7.2.1852

Ducas, A. M., \& Michaud-Oystryk, N. (2003). Toward a new enterprise: Capitalizing on the faculty-librarian partnership. College \& Research Libraries, 64(1), 55-74. https://doi.org/10.5860/crl.64.1.55

Eng, S., \& Stadler, D. (2015). Linking library to student retention: A statistical analysis. Evidence Based Library and Information Practice, 10(3), 50-63. https://doi.org/10.18438/B84P4D

Feldman, D., \& Sciammarella, S. (2000). Both sides of the looking glass: Librarian and teaching faculty perceptions of librarianship at six community colleges. College \& Research Libraries, 61(6), 491-497. https://doi.org/10.5860/crl.61.6.491

Grafstein, A. (2002). A discipline-based approach to information literacy. The Journal of Academic Librarianship, 28(4), 197-204. https://doi.org/10.1016/So0991333(02)00283-5

Hall, R. A. (2008). The "embedded" librarian in a freshman speech class: Information literacy instruction in action. College \& Research Libraries News, 69(1), 28-30. https://doi.org/10.5860/crln.69.1.7922

Hardesty, L. (1995). Faculty culture and bibliographic instruction: An exploratory analysis. Library Trends, 44(2), 339-368.

Hayes, J., McNeilly, S., \& Juanson, P. (2018). Getting things to POP: How collaboration, umbrellas and popcorn machines changed the relevancy of the Auburn University at Montgomery library. In V. Gubnitskaia \& C. Smallwood (Eds.), The relevant library: 
Essays on adapting to changing needs (pp. 14-22). Jefferson, NC: McFarland \& Company, Inc.

Head, A. J. (2013, April 10-13). Project information literacy: What can be learned about the information-seeking behavior of today's college students? [Paper Presentation]. Association of College and Research Librarians Conference 2013, Indianapolis, IN, United States. https://dx.doi.org/10.2139/ssrn.2281511

Hicks, A., \& Lloyd, A. (2021). Deconstructing information literacy discourse: Peeling back the layers in higher education. Journal of Librarianship \& Information Science, 53(4), 559571. https://doi.org/10.1177/0961000620966027

Johnson-Grau, G., Archambault, S. G., Acosta, E. S., \& McLean, L. (2016). Patience, persistence, and process: Embedding a campus-wide information literacy program across the curriculum. The Journal of Academic Librarianship, 42(6), 750-756.

https://doi.org/10.1016/j.acalib.2016.10.013

Kim, S. U., \& Shumaker, D. (2015). Student, librarian, and instructor perceptions of information literacy instruction and skills in a first year experience program: A case study. The Journal of Academic Librarianship, 41(4), 449-456. https://doi.org/10.1016/j.acalib.2015.04.005

Kline, E., Wallace, N., Sult, L., \& Hagedon, M. (2017). Embedding the library in the LMS: Is it a good investment for your organization's information literacy program? In T. Maddison \& M. Kumaran (Eds.), Distributed learning: Pedagogy and technology in online information literacy instruction. (pp. 255-269). Elsevier. https://doi.org/10.1016/B9780-08-100598-9.00014-3

Kotter, W. R. (1999). Bridging the great divide: Improving relations between librarians and classroom faculty. The Journal of Academic Librarianship, 25(4), 294-303. https://doi.org/10.1016/Soog9-1333(99)80030-5

Leckie, G., \& Fullerton, A. (1999). Information literacy in science and engineering undergraduate education: Faculty attitudes and pedagogical practices. College \& Research Libraries, 60(1), 9-29. https://doi.org/10.5860/crl.60.1.9

Leeder, C., \& Lonn, S. (2014). Faculty usage of library tools in a learning management system. College \& Research Libraries, 75(5), 641-663. https://doi.org/10.5860/crl.75.5.641

Lopez, K. A., \& Willis, D. G. (2004). Descriptive versus interpretive phenomenology: Their contributions to nursing knowledge. Qualitative Health Research, 14(5), 726-735. https://doi.org/10.1177/1049732304263638 
Maughan, P. D. (2001). Assessing information literacy among undergraduates: A discussion of the literature and the University of California-Berkeley assessment experience. College \& Research Libraries, 62(1), 71-85. https://doi.org/10.5860/crl.62.1.71

McGuinness, C. (2006). What faculty think- Exploring the barriers to information literacy development in undergraduate education. The Journal of Academic Librarianship, 32(6), 573-582. https://doi.org/10.1016/j.acalib.2006.06.002

Meulemans, Y., \& Carr, A. (2013). Not at your service: Building genuine faculty-librarian partnerships. Reference Services Review, 41(1), 80-90. https://doi.org/10.1108/00907321311300893

Moran, C. (2019). Disconnect: Contradictions and disagreements in faculty perspectives of information literacy. Reference Librarian, 60(3), 149-168. https://doiorg.queens.ezproxy.cuny.edu/10.1080/02763877.2019.1572573

Mounce, M. (2010). Working together: Academic librarians and faculty collaborating to improve students' information literacy skills: A literature review 2000-2009. The Reference Librarian, 51(4), 300-320. https://doi.org/10.1080/02763877.2010.501420

Perry, H. (2017). Information literacy in the sciences: Faculty perception of undergraduate student skill. College \& Research Libraries, 78(7). https://doi.org/10.5860/crl.78.7.964

Pinto, M. (2016). Assessing disciplinary differences in faculty perceptions of information literacy competencies. Aslib Journal of Information Management, 68(2), 227-247. https://doi.org/10.1108/AJIM-05-2015-0079

Raven, M. (2012). Bridging the gap: Understanding the differing research expectations of firstyear students and professor. Evidence Based Library and Information Practice, 7(3), 431. https://doi.org/10.18438/B8WG79

Rosman, T., Peter, J., Mayer, A.-K., \& Krampen, G. (2018). Conceptions of scientific knowledge influence learning of academic skills: Epistemic beliefs and the efficacy of information literacy instruction. Studies in Higher Education, 43(1), 96-113. https://doi.org/10.1080/03075079.2016.1156666

Sanborn, L. (2005). Perspectives on... Improving library instruction: Faculty collaboration. The Journal of Academic Librarianship, 31(5), 477-481.

https://doi.org/10.1016/j.acalib.2005.05.010

Sandercook, P. (2016). Instructor perceptions of student information literacy: Comparing international IL models to reality. Journal of Information Literacy, 10(1), 3-29. https://doi.org/10.11645/10.1.2065 
Saunders, L. (2012). Faculty perspectives on information literacy as a student learning outcome. Journal of Academic Librarianship, 38(4), 226-236.

https://doi.org/10.1016/j.acalib.2012.06.001

Saunders, L. (2013, April 10-13). Culture and collaboration: Fostering integration of information literacy by speaking the language of faculty. [Paper Presentation]. Association of College and Research Librarians Conference 2013, Indianapolis, IN, United States. http://www.ala.org/acrl/sites/ala.org.acrl/files/content/conferences/confsandpreconfs/ 2013/papers/Saunders Culture.pdf

Selegean, J. C., Thomas, M. L., \& Richman, M. L. (1983). Long-range effectiveness of library use instruction. College \& Research Libraries, 44(6), 476-480.

https://doi.org/10.5860/crl $4406 \quad 476$

Shaw, R. (2010). QM3: Interpretative phenomenological analysis. In M. Forrester (Ed.), Doing qualitative research in psychology: A practical guide (pp. 177-201). Thousand Oaks, CA: Sage Publications Inc.

Shosha, G. A. (2012). Employment of Colaizzi's strategy in descriptive phenomenology: A reflection of a researcher. European Scientific Journal, ESJ, 8(27) 31-43.

Singh, A. (2005). A report on faculty perceptions of students' information literacy competencies in journalism and mass communication programs: The ACEJMC survey. College \& Research Libraries, 66(4), 294-310. https://doi.org/10.5860/crl.66.4.294

Smith, J. A., Flowers, P., \& Larkin, M. (2009). Interpretative phenomenological analysis: Theory, method and research. Thousand Oaks, CA: Sage Publications, Inc.

Snavely, L., \& Cooper, N. (1997). Competing agendas in higher education: Finding a place for information literacy. Reference \& User Services Quarterly, 37(1), 53-62.

Soria, K. M., Fransen, J., \& Nackerud, S. (2017). The impact of academic library resources on undergraduates' degree completion. College \& Research Libraries, 78(6), 812-823. https://doi.org/10.5860/crl.78.6.812

Squibb, S. D., \& Mikkelsen, S. (2016). Assessing the value of course-embedded information literacy on student learning and achievement. College \& Research Libraries, 77(2), 164183. https://doi.org/10.5860/crl.77.2.164

Vander Meer, P. F., Perez-Stable, M. A., \& Sachs, D. E. (2012). Framing a strategy: Exploring faculty attitudes toward library instruction and technology preferences to enhance information literacy. Reference \& User Services Quarterly, 52(2), 109-122.

VanScoy, A., \& Evenstad, S. B. (2015). Interpretative phenomenological analysis for LIS research. Journal of Documentation, 71(2), 338-357. http://dx.doi.org/10.1108/JD-09$\underline{2013-0118}$ 
Wang, R. (2006). The lasting impact of a library credit course. Portal: Libraries and the Academy, 6(1), 79-92. https://doi.org/10.1353/pla.2006.0013

Weiner, S. A. (2014). Who reaches information literacy competencies? Report of a study of faculty. College Teaching, 62(1), 5-12. https://doi.org/10.1080/87567555.2013.803949

White-Farnham, J., \& Gardner, C. (2014). Crowdsourcing the curriculum: Information literacy instruction in first-year writing. Reference Services Review, 42(2), 277-292. https://doi.org/10.1108/RSR-09-2013-0046

Wojnar, D. M., \& Swanson, K. M. (2007). Phenomenology: An exploration. Journal of Holistic Nursing, 25(3), 172-180. https://doi.org/10.1177/0898010106295172

Wong, S. H. R., \& Cmor, D. (2011). Measuring association between library instruction and graduation GPA. College \& Research Libraries, 72(5), 464-473. https://doi.org/10.5860/crl-151

Yousef, A. (2010). Faculty attitudes toward collaboration with librarians. Library Philosophy and Practice, (2010), 1-14. https://digitalcommons.unl.edu/cgi/viewcontent.cgi?article=1530\&context=libphilprac

Zanin-Yost, A., \& Dillen, C. (2019). Connecting past to future needs: Nursing faculty and librarian collaboration to support students' academic success. Journal of Library Administration, 59(1), 45-58. https://doi.org/10.1080/01930826.2018.1549407 